\title{
Contrasted greenhouse gas emissions from local versus long-range tomato production
}

\author{
Michaela Clarissa Theurl • Helmut Haberl • \\ Karl-Heinz Erb • Thomas Lindenthal
}

Accepted: 18 June 2013 / Published online: 16 August 2013

(C) The Author(s) 2013. This article is published with open access at Springerlink.com

\begin{abstract}
Transport from regional production requires less fossil fuel and thus produces lower greenhouse gas emissions. In addition, policies fostering the production of regional goods support rural development. Tomato consumption has increased fast in Europe over the last decade. Intensive production techniques such as heated greenhouses and long-distance transport overcome seasonal constraints in order to provide year-round fresh goods. However, studies that evaluate seasonal and off-season production are scarce. Here, we analyzed the carbon footprint of tomato production systems in Austria, Spain, and Italy using a life cycle approach. We collected data from four main supply chains ending at the point of sale in an average Austrian supermarket. We aimed to identify hotspots of greenhouse gas emissions from agricultural production, heating, packaging, processing, and transport. Our results show that imported tomatoes from Spain and Italy have two times lower greenhouse gas emissions than those produced in Austria in capital-intensive heated systems. On the contrary, tomatoes from Spain and Italy were found to have 3.7 to 4.7 times higher greenhouse gas emissions in comparison to less-intensive organic production systems in Austria. Therefore, greenhouse gas emissions from tomato production highly depend on the production system such as the prevalence or absence of heating.
\end{abstract}

Keywords Greenhouse gas emissions (GHGE) • Tomato • Life cycle analysis (LCA) · Regional production · Transport

\footnotetext{
M. C. Theurl · T. Lindenthal

Research Institute of Organic Agriculture Austria,

Seidengasse 33-35/13, 1070 Vienna, Austria

M. C. Theurl $(\square) \cdot$ H. Haberl $\cdot$ K.-H. Erb

Institute of Social Ecology Vienna (SEC), Alpen-Adria

Universitaet Klagenfurt, Graz, Wien,

Schottenfeldgasse 29, 1070 Vienna, Austria

e-mail: michaela.theurl@fibl.org
}

\section{Introduction}

Reconciling the increasing resource demand in industrialized countries with sustainability goals presents a formidable challenge. As stated by the Food and Agriculture Organization of the United Nations (FAO 2006), this challenge is aggravated by a limited causal understanding of production-consumption links in an increasingly globalized world. Furthermore, significant data gaps related to the environmental impacts of the production, distribution, and consumption of products used in daily life still prevail. This is particularly valid for food supply. Consumers are confronted with an increasing variety and availability of goods and products; seasonal constraints related to the availability of, e.g., fruits or vegetables, are rendered insignificant due to the farreaching scope of long-distance transport and availability of greenhouse technologies.

With respect to fresh produce, tomatoes have become the most popular vegetable over recent decades. Worldwide, there was an increase of $+419 \%$ in production from 1960 to 2009, with an increase of area and yield from 2000 to 2009 of 24 and $4 \%$, respectively (Statistical Database of the FAO 2010). In Europe, tomato consumption increased by $21 \%$ from 2000 to 2007 , amounting to $44 \mathrm{~kg}$ per capita and subsequently dropping to $32 \mathrm{~kg}$ per capita in 2009. Austria's current tomato consumption is $25 \mathrm{~kg}$ per capita, not far below the European average (Statistical Office of the European Communities 2011).

Tomato production is based on a huge range of production techniques that are associated with different material, energetic, and technological requirements (Fig. 1). Concerning tomato production, the environmental impacts of different production sites and technologies at the farm stage have been studied in detail (Boulard et al. 2011; Torrellas et al. 2012; Williams et al. 2006). There are studies that explicitly investigate the advantageous environmental performance of different organic cultures compared to conventional farming 


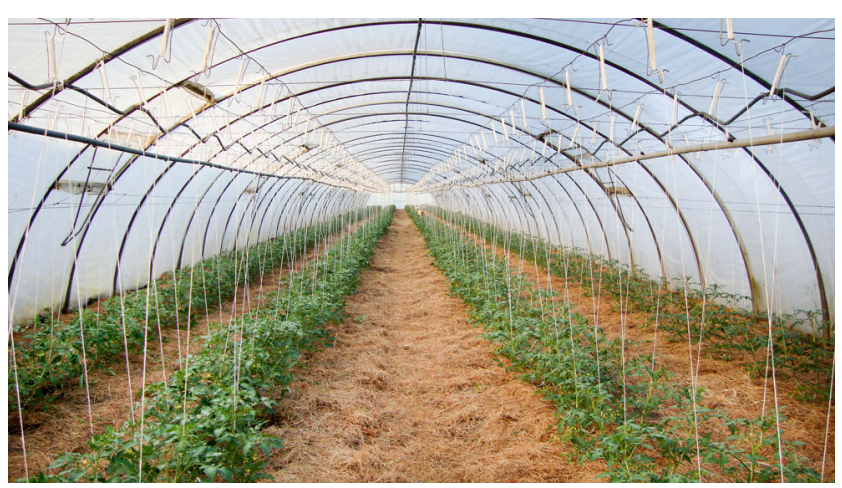

Fig. 1 Regional organic tomato cultivation in unheated plastic tunnels in Austria

practices (Lindenthal et al. 2010; Meisterling et al. 2009). Some research has been conducted to systematically compare the environmental burdens resulting from the entire tomato supply chain to the retailer in a manner that integrates agricultural production, including its upstream requirements, with those of the transport chains (Roy et al. 2008; Sim et al. 2007; Blanke and Burdick 2005; Andersson et al. 1998).

In consequence, the environmental impact related to tomato consumption varies considerably between different supply chains. In order to overcome seasonal or climatic constraints, tomatoes are transported from distant regions within other climate zones or produced around the year in heated greenhouses. A synoptic analysis that investigates options for climate mitigation in along tomato supply chain in northern Europe has not been undertaken so far.

Many policies and political campaigns foster the production of regional goods, also with the aim of supporting the development of rural areas. In Europe, for example, the European Council supports the development of rural areas as part of a new, market-oriented Common Agricultural Policy (Council of the European Union 2006). The market-oriented policy is based on direct payments as an incentive to farmers to adapt to the market conditions and is intended to improve competiveness in agricultural business (European Commission 2010). Furthermore, climate adaption strategies have gained importance in agriculture and led the Austrian Ministry of Life to make recommendations for action (BMLFUW 2012). In this context, the benefits of organic farming practices are the focus of intensive discussion (International Federation of Organic Agriculture Movements) (Bitan et al. 2009).

At the same time, it is intuitively plausible that regional products require less transport because fewer tonnekilometers are traveled and consequently less fuel is consumed and greenhouse gas emissions related to their transport are smaller. Studies of different foodstuffs imported to Europe emphasize the growing importance of global transportation (Knudsen et al. 2010; Blanke and Burdick 2005).

However, most scientific studies which provide the basis for policy making either assess the environmental impacts of different agricultural production technologies or the impacts related to transport. This study aims to help close this gap by following an integrative approach regarding the greenhouse gas emissions arising from a fresh vegetable supply chain. We report on a study that has systematically assessed total upstream emissions of greenhouse gases from production, transport, and packaging of the most important tomato products available for purchase in the average supermarket in Vienna, Austria, including tomatoes grown in conventional and organic systems from three regions: Austria, Spain, and Italy. The study aims to analyze hotspots of greenhouse gas emissions in the respective supply chains in order to prioritize reduction measures related to the production, supply, and consumption of tomatoes.

\section{Materials and methods}

The objective of the study was to compare the greenhouse gas emissions related to tomatoes from three different regions at the point of sale in a Viennese supermarket. We have considered introducing a functional unit tailored to consumer communication. This differs substantially to existing life cycle analysis of tomatoes in the literature (Boulard et al. 2011; Williams et al. 2006), where the functional unit refers to $1 \mathrm{~kg}$ loose product. In this study, the functional unit refers to $1 \mathrm{~kg}$ packed tomato. Tomatoes that are produced in Austria and Spain are packed in plastic boxes and tomatoes grown in Italy are processed and canned.

The basis of the underlying analysis comprises four key production systems, which represent practical examples of relevant tomatoes production systems supplying the Austrian market. The study is based on the standard life cycle assessment (LCA) methodology (ISO 14040). In order to calculate the global warming potential related to the supply chains, emissions of carbon dioxide $\left(\mathrm{CO}_{2}\right)$, methane $\left(\mathrm{CH}_{4}\right)$ and nitrous oxide $\left(\mathrm{N}_{2} \mathrm{O}\right)$ are converted into $\mathrm{CO}_{2}$ equivalents using factors from the guidelines of the Intergovernmental Panel on Climate Change (2006). The calculation of the different production inputs within the system boundary is based on data sets related to Austria from the Global Emission Model for Integrated Systems ("GEMIS Österreich v4.6" Umweltbundesamt 2010) and the EcoInvent database v2.0 (ecoinvent 2008).

Our study considers agricultural production, including upstream processes such as production of mineral and organic fertilizer or compost and transport of inputs to the farm site, e.g., fertilizer, compost, and greenhouse infrastructure (Fig. 2). Emissions stemming from the agricultural stage such as machine use, heating, or changes in soil organic carbon are considered. After harvest, tomatoes are packed directly at the production plant in Austria. Tomatoes cultivated in Spain are packed at the collection point and therefore a short transport distance was considered in the calculation. In Italy, the harvested product is transported to a processing plant, where 


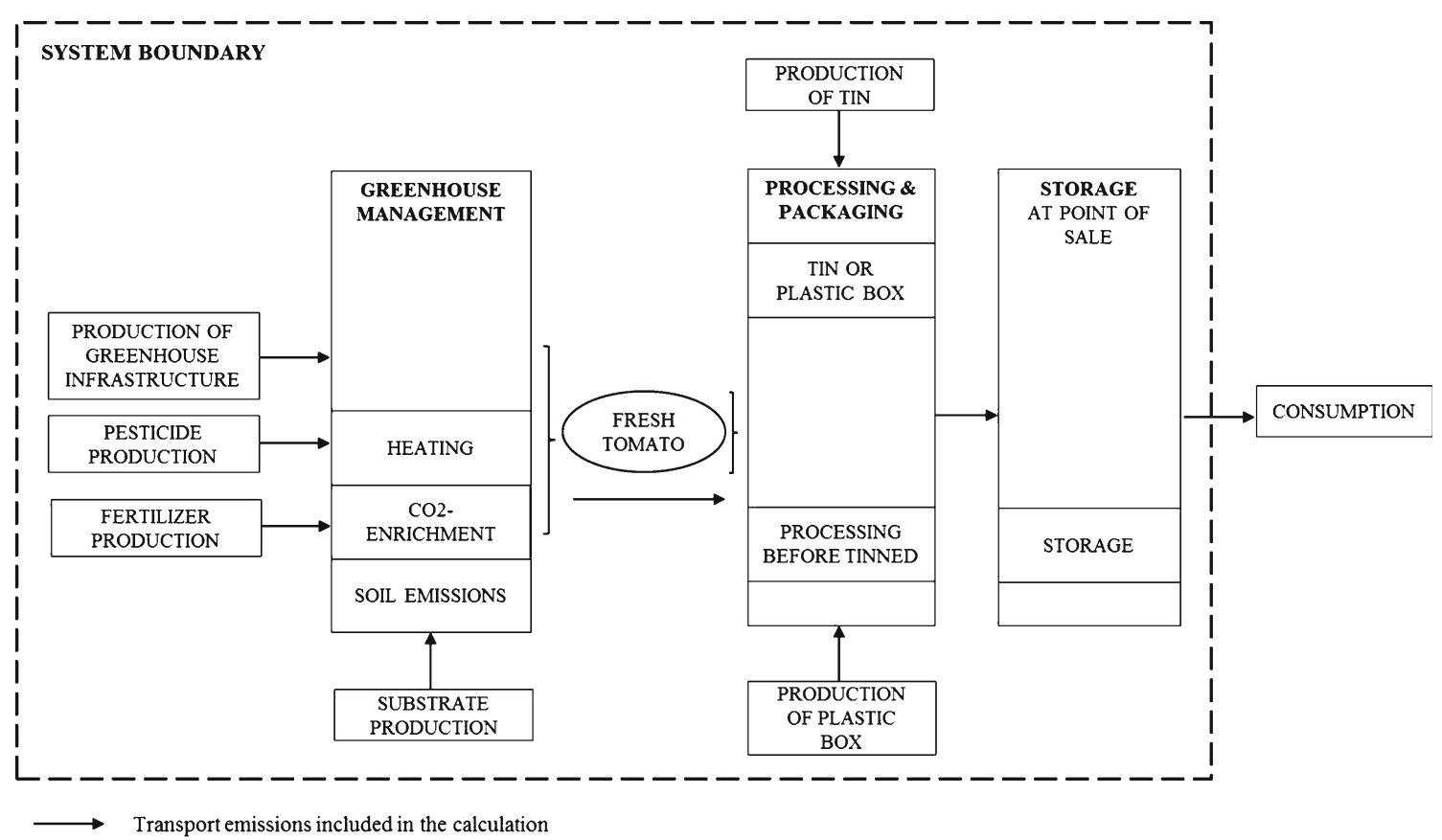

Fig. 2 System boundary represents items within dashed lines that are analyzed in the supply chain of the tomato production systems studied

the material is processed and canned. The final transport to the point of sale in an average Viennese supermarket is included in the analysis (Fig. 2). The transportation distance is documented in Table 1.

\subsection{Characteristics of the tomato production systems}

The area used in Austria for tomato production is relatively small (172 hectares in 2008-2009; Statistik Austria 2010). During the winter months, Almería is the most important vegetable producer for the European market. In 2011, 27 \% of Austria's fresh tomato imports came from Spain and $34 \%$ from Italy. Italy is also the leading producer of canned tomatoes within Europe (Statistical Databases of the FAO 2007) and is the leading supplier of supermarkets in Austria.

The main region for intensive vegetable production is located south of Vienna. This is the main production area for intensive conventional tomatoes under modern artificial substrate-based Venlo systems (system 1). The houses have plexiglass and aluminum constructions and high walls and are supplied with district heating mostly between November and March. In order to address the potential use of renewable energy, we present a variant of system 1 with wood chip heating using the same energy requirement as reported in Table 1.

Organic tomato production is of major significance in Austria, with production sites in the eastern and southern parts of the country (system 2; Fig. 1). Cultivation takes place in soil systems under plastic tunnels because the climate is sufficiently favorable to non-heated systems. Recently, heated tunnel systems have also gained importance in organic farming. In order to address the emissions from heating, we evaluate a variant of system 2 that considers year-round heating with wood chips. Typical plastic tunnels in Austria have one layer (a double plastic layer in the heated scenario) and are soil-grown systems. In order to show the potential of carbon sequestration through organic farming, we consider the effect of humus accumulation in system 2 and depletion in the open field system.

In 2008-2009, the cultivation area of tomatoes was estimated to be 8,500 ha in Almería, in southern Spain. In this region, a whole-year production of tomatoes take places within three cycles, from which 2,600 ha are under integrated pest management (IPM). IPM mainly consists in substituting the use of pesticides to combat tomato pests and diseases with biological measures, which are beneficial organisms such as ladybirds or damsel bugs. The production in Spain is characterized by multi-tunnel houses employing a solid steel construction, concrete blocks, and plastic cover and is dominated by conventional management techniques (system 3 ).

Tomatoes for the processing industry are mainly grown in the open field without protection (system 4). Apulia is the most important region in southern Italy, from where canned tomatoes are distributed all over Europe. Due to cultivation in the open field, with exposure to sun and drought, this system has the shortest cultivation period and the lowest yields. Organic cultivation is not prevalent in this region.

\subsection{Data elaboration}

Relative volumes supplied by different tomato production systems were estimated, based on statistical data (Statistik 
Table 1 Main characteristics of the four key production systems Venlo, tunnel, multi-tunnel, and open field in the three regions of Austria, Spain, and Italy

\begin{tabular}{|c|c|c|c|c|}
\hline Item & $\begin{array}{l}\text { System 1: } \\
\text { Venlo, Austria } \\
\text { Conventional }\end{array}$ & $\begin{array}{l}\text { System 2: } \\
\text { tunnel, Austria } \\
\text { Organic }\end{array}$ & $\begin{array}{l}\text { System 3: } \\
\text { multi-tunnel, Spain } \\
\text { Conventional }\end{array}$ & $\begin{array}{l}\text { System 4: } \\
\text { open field, Italy } \\
\text { Conventional }\end{array}$ \\
\hline Substrate & Rock wool & Soil & Sandy soil & Soil \\
\hline Greenhouse structure & $\begin{array}{l}\text { Steel, aluminum, } \\
\text { glass, concrete }\end{array}$ & Plastic & $\begin{array}{l}\text { Steel, plastic, } \\
\text { concrete }\end{array}$ & No \\
\hline Heating & Yes & No & No & No \\
\hline Yield $\left(\mathrm{kg} \mathrm{m}^{-2}\right.$ year $\left.^{-1}\right)$ & 50 & 16 & 13 & 74 \\
\hline Energy source & District heating & No & No & No \\
\hline $\mathrm{CO}_{2}$ enrichment & Yes & No & No & No \\
\hline Distance to point of sale $\mathrm{km}$ & 6 & 70 & 2,683 & 1,608 \\
\hline Mineral fertilizer $\left(\mathrm{N} \mathrm{kg} \mathrm{ha}^{-1}\right.$ year $\left.^{-1}\right)$ & 1,391 & No & 750 & 143 \\
\hline Mineral fertilizer $\left(\mathrm{P} \mathrm{kg} \mathrm{ha}^{-1}\right.$ year $\left.^{-1}\right)$ & 302 & No & 149 & 68 \\
\hline Mineral fertilizer $\left(\mathrm{K} \mathrm{kg} \mathrm{ha}^{-1}\right.$ year $\left.^{-1}\right)$ & 2,179 & No & 1,173 & 183 \\
\hline Manure compost $\left(\mathrm{N} \mathrm{kg} \mathrm{ha}{ }^{-1}\right.$ year $\left.^{-1}\right)$ & No & 240 & 700 & 400 \\
\hline Organic fertilizer $\left(\mathrm{N} \mathrm{kg} \mathrm{ha}{ }^{-1}\right.$ year $\left.^{-1}\right)$ & No & 60 & No & No \\
\hline Legumes $\left(\mathrm{N} \mathrm{kg} \mathrm{ha}{ }^{-1}\right.$ year $\left.^{-1}\right)$ & No & 50 & No & No \\
\hline Pesticides $\left(\mathrm{kg} \mathrm{ha}^{-1}\right.$ year $\left.^{-1}\right)$ & 8 & No & 26 & 56 \\
\hline Steel $\left(\mathrm{kg} \mathrm{ha}^{-1}\right.$ year $\left.^{-1}\right)$ & 5,500 & 781 & No & No \\
\hline Aluminum $\left(\mathrm{kg} \mathrm{ha}^{-1}\right.$ year $\left.^{-1}\right)$ & 1,250 & No & No & No \\
\hline Glass $\left(\mathrm{kg} \mathrm{ha}^{-1}\right.$ year $\left.^{-1}\right)$ & 6,700 & No & No & No \\
\hline Plexiglas $\left(\mathrm{kg} \mathrm{ha}^{-1}\right.$ year $\left.^{-1}\right)$ & 583 & No & No & No \\
\hline Plastics $\left(\mathrm{kg} \mathrm{ha}^{-1}\right.$ year $\left.^{-1}\right)$ & No & 406 & 2,624 & No \\
\hline Iron $\left(\mathrm{kg} \mathrm{ha}^{-1}\right.$ year $\left.^{-1}\right)$ & No & No & 4,563 & No \\
\hline Concrete $\left(\mathrm{kg} \mathrm{ha}^{-1}\right.$ year $\left.^{-1}\right)$ & 25,203 & No & 6,377 & No \\
\hline Rockwool (kg ha ${ }^{-1}$ year $\left.^{-1}\right)$ & 4,390 & No & No & No \\
\hline Energy demand heating (GJ year ${ }^{-1}$ ) & 7,906 & No & No & No \\
\hline Machine use $\left(\mathrm{h} \mathrm{ha}^{-1}\right)$ & 310 & 56 & 125 & 59 \\
\hline Storage $\left(\mathrm{MJ} \mathrm{kg}^{-1}\right)$ & 0.1 & 0.1 & 0.1 & 0.1 \\
\hline Processing ( $\mathrm{MJ} \mathrm{kg}^{-1}$ ) & No & No & No & 1.3 \\
\hline Tinplate $\left(\mathrm{g} \mathrm{kg}^{-1}\right)$ & No & No & No & 320 \\
\hline Plastic box $\left(\mathrm{g} \mathrm{kg}^{-1}\right)$ & 28 & 28 & 28 & No \\
\hline
\end{tabular}

Austria 2008; Junta de Andalucía 2009). Data on greenhouse infrastructure, greenhouse management systems, such as heating energy, cultivation cycles and yield, transport, and distribution to an average Viennese supermarket were gathered in interviews with experts in plant science, cultivation advisors, and distribution management from supermarkets. Furthermore, technical reports and scientific literature were screened and helped to fill data gaps (e.g., Andersson et al. 1998 and Gázquez 2007). The underlying data for the life cycle impact assessment of productions systems in Austria, Spain, and Italy are documented in Table 1. System 4, the open field system in the Apulia region in Italy, is based on primary unpublished data from Elia (2008 personal communication) and the scientific literature (Elia et al. 2007). Detailed information and data not shown here can be requested from the authors and are freely available online (Theurl 2008).
In order to show the potential significance of packaging for tomatoes at the point of sale, we consider plastic boxes in the calculation of systems 1 to 3 . Greenhouse gas emissions related to canned tomatoes are evaluated in system 4 . We wanted to analyze the influence of boxes made from polyethylene terephthalate (PET) material and tin plate cans on the total global warming potential of the produce.

In agricultural systems, emissions of nitrous oxide $\left(\mathrm{N}_{2} \mathrm{O}\right)$ are a significant contributor to global greenhouse gas emissions (IPCC 2006). Direct $\mathrm{N}_{2} \mathrm{O}$ emissions occur directly from the soil, to which the nitrogen in the form of fertilizers is applied. Indirect $\mathrm{N}_{2} \mathrm{O}$ emissions from soil processes occur from volatilization of ammonia and generic forms of nitrogen and after leaching of nitrogen in the form of nitrate. In this study, we calculated $\mathrm{N}_{2} \mathrm{O}$ emissions according to the IPCC guidelines (2006) with some adjustments. Firstly, the 
emission factor for compost and manure was adjusted to $0.5 \%$ instead of $1 \%$ as proposed by the IPCC. We argue that nitrogen is bound less solidly in organic materials than in mineral fertilizers. Secondly, in the case of soil-less cultures on rock wool, we assumed that the concentration of nitrogen of the liquid fertilizer deposit via drip irrigation is very low and therefore $\mathrm{N}_{2} \mathrm{O}$ emissions are negligible.

\section{Results and discussion}

The results of our study show that regional production must not be equated with low greenhouse gas emissions under all circumstances, e.g., if regional production requires the use of heating systems, when production abroad can proceed without heating. Even substantial emissions from long-distance transport or processing and packaging may be lower than those associated with producing vegetables in the cold season in central Europe. The analysis suggests that any evaluation of the total climate impacts of food products needs to consider the entire supply chain, including agricultural production, distributional transport, and packaging.

Based on the results of such studies, relevant strategies of the Council of the European Union (2006) that aim to support the development of rural areas with its regional production and shorter transport routes can be examined. The results, presenting greenhouse gases arising from each life cycle stage, help to understand the climate performance of options for overcoming seasonal production restrictions in colder climates. The results highlight that a differentiated approach is required for reducing the global warming potential of products.

\subsection{Comparison of the production systems in the three study regions}

Table 2 records the global warming potential of tomatoes provided by four key supply systems at the point of sale in an average Viennese supermarket. Figure 3 presents the results in an aggregated form. The cultivation of organic tomatoes in plastic tunnels is associated with the lowest greenhouse gas emissions at the point of sale from all four systems, with absolute numbers of $180 \mathrm{~g} \mathrm{CO}_{2} \mathrm{e}$. Austrian tomatoes grown in Venlo houses are associated with the highest carbon emissions from all four supply chains investigated in the study, corresponding to $1,397 \mathrm{~g} \mathrm{CO}_{2} \mathrm{e}$ per $\mathrm{kg}$ product. Both imported tomatoes from Spain and canned tomatoes from Italy, at 759 and $868 \mathrm{~g} \mathrm{CO}_{2} \mathrm{e}$, respectively, produce nearly 1.5 to nearly 2 times lower greenhouse gas emissions than tomatoes from heated Austrian systems (Fig. 3).

The production of greenhouse elements such as steel and glass accounts for not more than $9 \%$ of the total global warming potential in the tomato production systems studied.
In system 1, the production of aluminum constructions is largely responsible for the $80 \mathrm{~g} \mathrm{CO}_{2} \mathrm{e}$ per $\mathrm{kg}$ tomatoes. The figure of 1 ton of aluminum employed per hectare of greenhouse area is remarkable. The production of plastic foil for the tunnels generally has a small effect on the total global warming potential ( $4 \mathrm{~g}$ in system 2 ), rising up to $43 \mathrm{~g} \mathrm{CO}_{2} \mathrm{e}$ per $\mathrm{kg}$ tomatoes in Spanish tunnels. The latter is equivalent to $2,624 \mathrm{~kg}$ plastic foil.

The production of fertilizers makes a contribution of about $27 \mathrm{~g} \mathrm{CO}_{2} \mathrm{e}$ to the total greenhouse gas emissions associated with conventional Venlo houses. Carbon emissions arising from the production of organic fertilizers such as vinasse and compost are negligible in the case of organic cultivation. System 3 in Almería has the highest global warming potential from nitrogen fertilizer input, with $44 \mathrm{~g}$ $\mathrm{CO}_{2} \mathrm{e}$, representing $10 \%$ of the total carbon emissions per $\mathrm{kg}$ product. The results show very high greenhouse gas emissions from fertilizer input in the Spanish systems compared to Austrian production. At the same time, this leads to remarkable nitrous oxide emissions in this study, $59 \mathrm{~g}$ $\mathrm{CO}_{2} \mathrm{e}$ per $\mathrm{kg}$ product, which are likely to be underestimated although we used the average standard leaching default value 0.3 in accordance with the IPCC guidelines (2006). The IPCC standard (2007) does not explicitly report on the fraction of leaching from drip irrigation. The data collected for the inventory report substantially higher amount of nitrogen fertilizer input for system 3 (Table 1). An explanation for the high absolute amounts of nitrogen fertilizer input in the Spanish productions systems is certainly the presence of inefficient management practices with large manure applications at greenhouse construction and insufficient consideration of the nitrogen amounts subsequently (Thompson et al. 2007). Nevertheless, in this study, we analyze a great heterogeneity of production systems and site-specific management decisions. According to the ranges of emission factors quoted in the IPCC guidelines (2006), it is very likely that the results provide uncertainties.

Carbon emissions from pesticide production on one hand emerge as negligible in system 3 and may not need to be accounted for, as the system relates to integrated pest management and the data on pesticide input refer to applications in exceptional cases. On the other hand, relevant carbon emissions stemming from the production of pesticide do arise in the open field production system.

According to the results, the contribution of organic farming to carbon sequestration in tomato cropping is minimal. Despite intensive open field production, the results show only a slight humus decrease in system 4. Regarding these low numbers, it is questionable whether carbon sequestration should be considered in the calculation of carbon footprints of high productive vegetable systems and whether compensation mechanisms should be taken into account at all (Schmidt 2009). 
Table 2 Global warming potential for 100 years in gram $\mathrm{CO}_{2} \mathrm{e}$ for $1 \mathrm{~kg}$ of tomato product along the four key systems at the point of sale in an average Viennese supermarket

\begin{tabular}{|c|c|c|c|c|}
\hline Item & $\begin{array}{l}\text { System 1: } \\
\text { Venlo, Austria } \\
\text { Conventional }\end{array}$ & $\begin{array}{l}\text { System 2: } \\
\text { tunnel, Austria } \\
\text { Organic }\end{array}$ & $\begin{array}{l}\text { System 3: } \\
\text { multi-tunnel, Spain } \\
\text { Conventional }\end{array}$ & $\begin{array}{l}\text { System 4: } \\
\text { open field, Italy } \\
\text { Conventional }\end{array}$ \\
\hline Greenhouse infrastructure (subtotal) & 114 & 8 & 70 & 0 \\
\hline Steel & 6 & 3 & & \\
\hline Aluminum & 80 & & & \\
\hline Glass & 18 & & & \\
\hline Plexiglas & 2 & & & \\
\hline Plastic & & 5 & 43 & \\
\hline Iron & & & 19 & \\
\hline Concrete & 8 & & 8 & \\
\hline Fertilizing and pesticides (subtotal) & 27 & & 61 & 38 \\
\hline Mineral fertilizer $\mathrm{N}$ & 21 & & 44 & 15 \\
\hline Mineral fertilizer P & 0.74 & & 1.41 & 1.13 \\
\hline Mineral fertilizer $\mathrm{K}$ & 5.14 & & 10.65 & 2.92 \\
\hline Manure compost & & 0.04 & 0.07 & 0.20 \\
\hline Organic fertilizer & & 0.11 & & \\
\hline Pesticides & 0.39 & & 5 & 19 \\
\hline Soil (subtotal) & & 8 & 59 & 36 \\
\hline $\mathrm{N}_{2} \mathrm{O}$ emissions direct & & 5 & 40 & 22 \\
\hline $\mathrm{N}_{2} \mathrm{O}$ emissions indirect & & 4 & 19 & 14 \\
\hline Humus sequestration & & -0.75 & & 0.34 \\
\hline Greenhouse management (subtotal) & 1,144 & 5 & 103 & 12 \\
\hline $\mathrm{CO}_{2}$ fertilizing & 280 & & & \\
\hline Machine use & 8 & 5 & 24 & 12 \\
\hline Desalination plant & & & 79 & \\
\hline Rockwool & 8 & & & \\
\hline Heating requirement & 848 & & & \\
\hline Transport (subtotal) & 7 & 85 & 392 & 196 \\
\hline Transport short distance & 7 & 85 & 18 & 18 \\
\hline Transport long distance & & & 374 & 178 \\
\hline Storage & 3 & 3 & 3 & \\
\hline Processing and packaging (subtotal) & 71 & 71 & 71 & 586 \\
\hline Processing & & & & 139 \\
\hline Packaging & 71 & 71 & 71 & 447 \\
\hline $1 \mathrm{~kg}$ packed product & 1,367 & 180 & 680 & 868 \\
\hline $1 \mathrm{~kg}$ fresh loose product & 1,296 & 109 & 609 & 281 \\
\hline
\end{tabular}

A further relevant contributor to the agricultural production stage is $\mathrm{CO}_{2}$ fertilizing from stand-alone tanks, which accounts for $280 \mathrm{~g} \mathrm{CO}_{2}$ e per $\mathrm{kg}$ tomatoes in system 1 .

The major share of the emissions from the agricultural stage in soil-less Venlo systems originates from "greenhouse management" that includes heating and $\mathrm{CO}_{2}$ fertilization, whereby carbon emission from heating is the dominant factor. A consistent result for unheated soil-grown tomato systems is found, i.e., that emissions from the agriculture are considerably lower and are dominated by emissions from nitrogen fertilizer application and production. Using $1 \mathrm{~kg}$ tomatoes as the functional unit enables a reliable comparison of production systems but does not refer to a difference in fruit quality. In comparison with greenhouse gas emission arising at farm stage from previous studies, carbon emissions differ slightly in the respective production systems (Table 11, Boulard et al. 2011).

Energy consumption from storage of the fresh tomatoes is associated with very low greenhouse gas emissions. Even in system 2 , where the total global warming potential appears to 
Global Warming Potential $\left(\mathrm{g} \mathrm{CO}_{2} \mathrm{e} \mathrm{kg}^{-1}\right)$

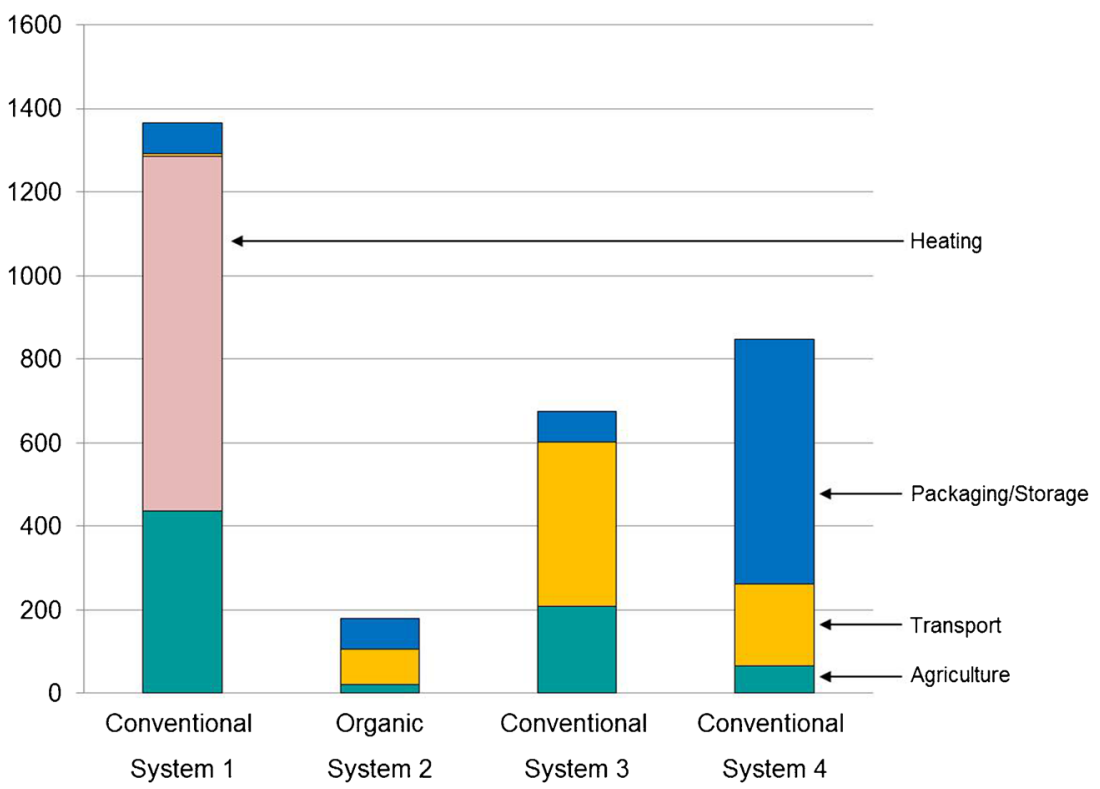

Fig. 3 Global warning potential of the key supply chains for tomatoes in absolute gram $\mathrm{CO}_{2}$ per kilograms product at the point of sale in Austria. Total emissions are constituted by Agriculture that comprises fertilizers and pesticides, greenhouse infrastructure, soil, and greenhouse management except for Heating, which is declared separately; Packaging/Storage that includes storage, packaging, and processing stages; and Transport. A major hotspot is the Heating of Austrian Venlo houses (system 1), whereas Packaging/Storage is a relevant contributor to total greenhouse emissions in the case of Italian tomatoes (system 3). The highest greenhouse gas emissions from transportation arise in the case of Spanish tomatoes (system 3). Local Austrian tomatoes (system 2) are associated with low greenhouse gas emissions but are not available to consumers throughout the year

with $392 \mathrm{~g} \mathrm{CO}_{2}$ e per $\mathrm{kg}$ which corresponds to $58 \%$ of the total carbon emissions per kg product. In system 4 , transport accounts for $196 \mathrm{~g} \mathrm{CO}_{2} \mathrm{e}$, which equates to $23 \%$ of total greenhouse gas emissions per kg product at the point of sale in average supermarkets in Vienna.

The utilization of different data sources has a considerable impact on transport emissions. Here, the transport distance was $70 \mathrm{~km}$, whereas Lindenthal et al. (interim report 2009; unpublished) found similar transport emissions for Austrian tomatoes, although the distance was $270 \mathrm{~km}$ from the production site to the point of sale.

Weber and Matthews (2008) and Hawkins and Dente (2010) found that, in general, carbon emissions from transporting agricultural products represent $0.5 \%$ of total greenhouse gas emissions. This number correlates to the results of system 1 . In contrast, when tomato production systems are less intensive (system 2), emissions from transport are higher per kilogram product because transport emissions refer to a lower yield. Attention must be paid to the fact that the studies mentioned have used aggregated data for different production sections on national per capita consumption and have not exclusively investigated tomato products.

However, transportation of tomatoes from Spain or Italy does not raise the related greenhouse gas emissions to a level above that of heated greenhouse tomatoes; these results accord with results from a comparison of tomato production from transportation arise in the case of Spanish tomatoes

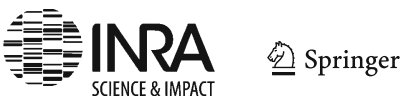


in Spain and Great Britain by Williams et al. (2008) or as recorded by Müller-Lindenlauf and Reinhard for lettuce and other products (2010), where expenditures for the transport of Mediterranean vegetables in winter months do not outweigh the disadvantage of regional production.

Another focal point of discussion is the impact of agricultural upstream transportation from, e.g., mineral fertilizers or compost to the production site. Based on the results of their investigation, Weber and Matthews (2008) arrive at the proposition that upstream transportation requirements remain more important than final delivery, when analyzing global warming potential with data of food consumption by US households. However, this aspect depends upon several assumptions regarding, e.g., location of production plant, distance, means of transport, and storage, and is usually included in the calculations from LCA databases such as EcoInvent (2008). However, the present study concludes that upstream transports related to agricultural production of tomatoes does not make an influential contribution to the total global warming potential for $1 \mathrm{~kg}$ tomatoes (amounting to less than $1.5 \%$, assuming a $200-\mathrm{km}$ transport distance). Furthermore, we based our calculations on an average load factor of $80 \%$ and one single transport distance from the location of production to the supermarket in Vienna was assumed and empty return trips were not taken into consideration. Although this could lead to uncertainty, there is evidence that load factors do not influence total greenhouse gas emissions per kilogram product (O’Donnell et al. 2009).

\subsubsection{Packaging}

Packaging was identified to be a major hotspot regarding greenhouse emissions along the supply chain of tomatoes. The influence of packaging upon the total global warming potential of a product depends on the type of packaging material and the tare weight. Furthermore, determining the amount of greenhouse gases arising from other life cycle stage is fundamental in considering whether the packaging stage represents a hotspot of a supply chain or not.

With reference to $1 \mathrm{~kg}$ tomatoes, the production of plastic containers made of PET causes greenhouse gas emissions of $71 \mathrm{~g} \mathrm{CO}_{2} \mathrm{e}$, whereas the production of the tins accounts for $447 \mathrm{~g} \mathrm{CO}_{2} \mathrm{e}$. Additionally, the processing stage preparing the fresh tomatoes accounts for $139 \mathrm{~g} \mathrm{CO}_{2} \mathrm{e}$ per $\mathrm{kg}$ canned tomatoes.

The results show that plastic packaging represents a hotspot in the supply chain of unheated organic tomatoes (system 2) but not in heated cultivation in Austria (system 1). Furthermore, tin packaging is clearly a hotspot in supply chains. In system 4, carbon emissions resulting from packaging and processing are up to seven times higher than emissions resulting from the farm stage.

\subsubsection{Heating}

Greenhouse gas emissions from heating glasshouses used in vegetable production are a central issue in northern countries. Williams et al. (2006) calculated energy inputs in standalone boiler-heated British greenhouses, where heating represented $97 \%$ of the total global warming potential of tomatoes. Due to the different forms of heating energy available, e.g., district heating with notably lower carbon emissions, our study finds that the proportion of the total global warming potential in this system is little more than $60 \%$. Compared to other studies, the heat requirement seems to be low in our study (Boulard et al. 2011; Torrellas et al. 2012). One reason is the reference unit used, in this case $1 \mathrm{~kg}$ packed tomatoes. Another major reason is the heating pause of 1 to 2 months usually in December and January and highly likely the favorable climate found in Vienna's suburbs.

In urban Vienna, district heating is prevalent now, but there are still houses using natural gas as primary energy carriers. Furthermore, glasshouses with older technologies are still in use. Under these circumstances, the proportion of total global warming potential from heating can be $80 \%$, when using natural gas is used without re-using the fumes for fertilizing (Theurl 2008). Note, however, that our assumptions on heating energy requirements were conservative, so that the related carbon emissions might be higher than the values reported in Table 2. The use of renewable energy sources in the form of wood chip heating would reduce total greenhouse gas emissions by $50 \%$ (Theurl 2008). In Austria, keeping plastic tunnels frost free gains importance in for soil-grown cultures and is partly allowed according to organic standards. Organic tunnels held frost free by the use of oil heating have significantly higher carbon emissions than glass house systems using district heating (Theurl 2008). Even where yearround heating is achieved through wood chips, higher carbon emissions arise in the case of plastic tunnel systems than in the case of Venlo or glass house systems. One reason for this is a higher energy demand due to a lower heat transfer coefficient of plastic material and another reason is the lower yields in soil systems (Theurl 2008).

In Austria, the market for organic products is still growing and the demand for domestically produced organic vegetables is rising accordingly. Therefore, heating options could become of a major focus for organic production, although increasing costs are certainly a limiting factor.

\subsection{Consumer's choice and policy}

The aggregated results of the study presented in Fig. 3 show that it is important to take an integrative view when analyzing the global warming potential of different tomato productions systems: the global warming potential of organic production outweighs that of conventional cultivation, but 
organic regional production has the lowest global warming potential in the growing season, yielding from June to September in Austria. A surprising result of the study is that the seasonally grown Italian canned tomatoes have a relatively high global warming potential due to processing and canning, which is nearly three times higher than the longdistance transport from Italy to Vienna. Interestingly, $\mathrm{CO}_{2}$ savings may be made in winter months in Austria by eating fresh tomatoes from Spain or canned tomatoes from Italy. A considerable $\mathrm{CO}_{2}$ reduction potential exists in the substitution of energy sources, replacing current district heating with wood chips heating in Austrian Venlo houses. Interestingly, the global warming potential of Austria's organic tomato tunnels requiring year-round heating with wood chips would outweigh that of the production of processed canned organic tomatoes from unheated tunnels (Theurl 2008).

In contrast to studies from Hauwermeiren et al. (2007), the present study found lower $\mathrm{CO}_{2}$ emissions in the case of locally grown tomatoes produced without heating in summer, which can be explained by the differences in the tomato production systems of the regions studied in each case. Decision makers should not simply implement existing policy strategies because this study demonstrates that supporting regional producers as a single measure is clearly not an effective strategy for reducing climate impacts. Strategies for reducing greenhouse gas emissions should therefore include encouraging individuals to refrain from eating fresh tomatoes from energy-intensive tomato production from greenhouses in northern countries or to eat fresh or canned tomatoes from southern parts of Europe during the winter months.

Furthermore, $\mathrm{CO}_{2}$ labeling of food products represents another important instrument in influencing consumer choices and this continues to be of growing interest also in terms of a broader implementation in the near future. In this context, it is very important to find ways to include production and transport to the retailer within the calculation used to ensure that labeling retains validity. From the policy perspective, consumers alone are not likely to be drivers for a transition from the existing food system to a decarbonized one. Rather, a targeted and coherent labeling policy is needed, which cannot succeed without establishing a robust linkage between policy and stakeholders, such as retailers (Gadema and Oglethorpe 2011; Schmidt 2009). Nevertheless, the instrument of life cycle accounting is already available and can help both to improve understanding of the sources from which greenhouse gas emissions arise and to identify where the optimization potential of product systems can be found (Schmidt 2009).

\section{Conclusion}

This comparison of various tomato production systems in Austria, Spain, and Italy shows that heating, packaging, and transport are the most important hot spots regarding greenhouse gas emissions associated with the different tomato supply chains. Emissions from fertilizer and pesticide production, soils, and infrastructures are relevant in the case of intensive conventional production systems. By far, the lowest carbon emissions stem from the unheated organic production system in Austria.

Heating is identified as having the major reduction potential in this study, which showed that greenhouse gas emissions from heating are higher than those from both longdistance road transport and energy-intensive processing and packaging.

Policies that promote local production irrespective of the emissions associated with the production stage risk creating adverse effects in terms of greenhouse gas emissions. Although only local production systems with low emissions related to transport, processing, and packaging can deliver low-emission products, these products may not be available throughout the year. Climate conditions prevent the production of commodities such as vegetables during winter months in regions like Central Europe. One solution to this supply problem may be the promotion of seasonal products, but the extent to which consumers will adopt such behavior and refrain from consuming such products out of season is difficult to predict, while the potential of policies to influence consumer behavior is also limited. Another strategy involves reducing the greenhouse gas emissions caused by heating glasshouses. Our calculations suggest that available technologies may reduce these emissions by approximately $50 \%$. In this case, greenhouse gas emissions from tomatoes grown in Austria under heated conditions would be similar to those imported from Italy or Almería, which still exceed the lowest levels found for seasonal locally produced fresh tomatoes by a factor of 4 .

We conclude that consideration of the entire supply chain, including transport and packaging, is required when comparing the levels of greenhouse gas emissions associated with different production systems. A switch to seasonal, organic, and locally grown products results in very large emission reductions of more than $85 \%$, compared to the consumption of average products. The most prevalent supply chains in Austria do not include any low-emission out-ofseason systems, e.g., wood heating. While we cannot preclude the existence of such systems, they do not play a major role in tomato production at the present time. Designing or identifying such supply chains and increasing their importance seem to be the only option for reducing greenhouse gas emissions associated with vegetable supply, unless consumers are prepared to effect a large-scale switch to seasonal products.

Acknowledgments The authors thank Rodney Thompson (University of Almería) for his supporting information; Esteban José Baeza, 
Antonio Céspedes-López (Estación Experimental de la Fundación Cajamar), and Antonio Elia (University of Foggia) for support with site-specific data in Almería and Puglia; and the two anonymous reviewers. We acknowledge support from the project P20812-G11 (Austrian Science Funds, www.fwf.ac.at), EU-FP7 265104 VOLANTE, and ERC-STG2010-263522 LUISE. This study contributes to the Global Land Project (www.globallandproject.org).

Open Access This article is distributed under the terms of the Creative Commons Attribution License which permits any use, distribution, and reproduction in any medium, provided the original author(s) and the source are credited.

\section{References}

Andersson K, Ohlsson T, Olsson P (1998) Screening life cycle assessment (LCA) of tomato ketchup: a case study. J Clean Prod 6:277288

Bitan E, Van Veluw K, Luske B, Scholberg J, Muller A, Bos M (2009) The contribution of organic agriculture to climate change mitigation. Publications of IFOAM EU Group

BMLFUW (2012) Die österreichische Strategie zur Anpassung an den Klima-wandel Teil 2 - AKTIONSPLAN Handlungsempfehlungen für die Umsetzung. http://www.lebensministerium.at/ umwelt/klimaschutz/klimapolitik_national/anpassungsstrategie/strategieaussendung.html. Accessed 30 Apr 2013

Boulard T, Raeppel C, Brun R, Lecompte F, Hayer F, Carmassi G, Gaillard (2011) Environmental impact of greenhouse tomato production in France. Agron Sustain Dev 31:757-777

Blanke M, Burdick B (2005) Food (miles) for thought — energy balance for locally-grown versus imported apple fruit (3 pp). Environ Sci Pollut R 12:125-127

Council of the European Union (2006) Council decision of 20 February 2006 on community strategic guidelines for rural development (programming period 2007 to 2013). Official Journal of the European Union

EcoInvent, d.v (2008) Database Version 2.01. EcoInvent Centre Inventories, S.C.f.L.C. (ed), St. Gallen, Switzerland

Elia A, Conversa G, La Rotonda P, Montemurro F (2007) Nitrogen level effect on yield and quality of fertigated processing tomato in Southern Italy. Acta hortic 758:235-240

European Commission (2010) Communication from the Commission to the European Parliament, The Council, The European Economic and Social Committee and the Committee of the Regions the CAP towards 2020: Meeting the food, natural resources and territorial challenges of the future

FAO (2006) World agriculture: towards 2030/2050 - interim report. Prospects for food, nutrition, agriculture and major commodity groups. FAO, Rome

FAO $(2007,2010)$ Statistical data. Available online at http://faostat.fao. org/site/567/default.aspx\#ancor. Accessed 9 Aug 2012

Gázquez JCG (2007) El cultivo del tomate: técnicas de cultivo. Report. Almería

Gadema Z, Oglethorpe D (2011) The use and usefulness of carbon labelling food: a policy perspective from a survey of UK supermarket shoppers. Food Policy 36(6):815-822

Hawkins TR, Dente SM (2010) Greenhouse gas emissions driven by the transportation of goods associated with French consumption. Environ Sci Technol 44:8656-8664

IPCC (2006) Guidelines for National Greenhouse Gas Inventories, Prepared by the National Greenhouse Gas Inventories Programme, Eggleston H.S., Buendia L., Miwa K., Ngara T. and Tanabe K. (eds). Japan
Junta de Andalucía (2009) Anuario Estadístico de Andalucía 2009. http://www.juntadeandalucia.es/institutodeestadisticaycartografia/ anuario/anuario10/anuario10c16.htm\#c660. Accessed 25 Sept 2012

Knudsen M, Yu-Hui Q, Yan L, Halberg N (2010) Environmental assessment of organic soybean (Glycine max.) imported from China to Denmark: a case study. J Clean Prod 18:1431-1439

Lindenthal T, Markut T, Hörtenhuber S, Theurl MC, Rudolph G (2010) Greenhouse gas emissions of organic and conventional foodstuffs in Austria. In: Settani E, Tassielli G, Giungato P (eds) Notarnicola B. VII International Conference on life cycle assessment in the Agri-Food Sector, Bari, pp 319-324

Meisterling K, Samaras C, Schweizer V (2009) Decisions to reduce greenhouse gases from agriculture and product transport: LCA case study of organic and conventional wheat. J Clean Prod 17:222-230

Müller-Lindenlauf M, Reinhard G (2010) Food import versus regional production: comparison of energy demand and greenhouse gas emissions. In: Settani E, Tassielli G, Giungato P (eds) Notarnicola B. VII International Conference on life cycle assessment in the Agri-Food Sector, Bari, pp 487-492

O'Donnell B, Goodchil A, Cooper J, Ozawa T (2009) The relative contribution of transportation to supply chain greenhouse gas emissions: a case study of American wheat. Transport Res D-Tr E 14(7):487-492

Roy P, Nei D, Okadome H, Nakamura N, Orikasa T, Shiina T (2008) Life cycle inventory analysis of fresh tomato distribution systems in Japan considering the quality aspect. J Food Eng 86:225-233

Schmidt HJ (2009) Carbon footprinting, labeling and life cycle assessment. Int J Life Cycle Ass 14(1):6-9

Sim S, Barry M, Clift R, Cowell S (2007) The relative importance of transport in determining an appropriate sustainability strategy for food sourcing. Int J Life Cycle Ass 12:422-431

Statistical Office of the European Communities (2011) http://appsso. eurostat.ec.europa.eu/nui/setupModifyTableLayout.do. Accessed 20 Apr 2013

Statistik Austria (2008) Gemüseernte 2008. Endgültige Ergebnisse, Wien

Statistik Austria (2010) Versorgungsbilanzen für pflanzliche Produkte 2008/09. Wien

Theurl MC (2008) CO2-Bilanz der Tomatenproduktion: Analyse acht verschiedener Produktionssysteme in Österreich, Spanien und Italien. http://www.uni-klu.ac.at/socec/inhalt/1818.htm. Accessed 30 Apr 2013

Thompson R, Martínez-Gaitan C, Gallardo M, Giménez C, Fernández $M$ (2007) Identification of irrigation and $\mathrm{N}$ management practices that contribute to nitrate leaching loss from an intensive vegetable production system by use of a comprehensive survey. Agric Water Manag 89(3):261-274

Torrellas M, Antón A, Ruijs M, García NV, Stanghellini C, Montero JI (2012) Environmental and economic assessment of protected crops in four European scenarios. J Clean Prod 28:45-55

Umweltbundesamt (2010) GEMIS-Österreich Version 4.6 Gesamt Emissions Modell Integrierter Systeme für Österreich. Umweltbundesamt

Weber CL, Matthews HS (2008) Food miles and the relative climate impacts of food choices in the United States. Environl Sci Technol 42(10):3508-3512

Williams AG, Pell E, Webb J, Moorhouse, E, Audsley E (2008) Strawberry and tomato production for the UK compared between the UK and Spain. In: Nemecek T and Gaillard G (eds) 6th International Conf. on LCA in the Agri-Food Sector, Zürich, pp 254-414

Williams AG, Audsley E, Sandars DL (2006) Determining the environmental burdens and resource use in the production of agricultural and horticultural commodities. Main report. Defra Research Project IS0205. Cranfield University and Defra, Bedford. http://www. defra.gov.uk. Accessed 30 Sept 2012

Van Hauwermeiren A, Coene H, Engelen G, Mathijs E (2007) Energy lifecycle inputs in food systems: a comparison of local versus mainstream cases. J Environ Policy and Plan 9(1):31-51 